\title{
Democratizing Party Leadership Selection in Belgium: Motivations and Decision Makers
}

\begin{abstract}
Bram Wauters
University College Ghent

Political parties are increasingly adopting more inclusive procedures to select their party leader, most notably by introducing party primaries. This article tries to detect motives and decision makers for this introduction in Belgian parties. The literature on Westminster-style parties contends that party elites only reluctantly transfer more power from the parliamentary party group (PPG) to party members. They do so only when finding themselves in a weak position: after electoral defeat, when in opposition, when other parties are doing so or when the party is new. The situation in Belgium is different, as is demonstrated with quantitative and qualitative data. Mostly, the party elite was keen on introducing party primaries and took the initiative itself to carry them through. The mechanism at work, however, is the same as in Westminster parties: avoiding too much power for middle-level elites. Because of the different starting position (party delegates selecting the leader), the decision-making process looks completely different. We also argue that the results from Belgian parties might apply to consensus democracies in general.
\end{abstract}

Keywords: Belgium; party leader; party members; primaries; leadership selection

Party change is a remarkable phenomenon. On the one hand, parties are thought to be conservative organisations that resist change (Harmel and Janda, 1994). On the other hand, an increasing number of parties have recently been changing their internal organisation, in particular by giving their grassroots members a greater formal say in the selection of the party leader (e.g. Cross and Blais, 2012; Denham, 2009; Kenig, 2009a; Leduc, 2001; Wauters, 2010). This change can be illustrated by a continuum on which leadership selection methods are classified according to their degree of inclusiveness (Kenig, 2009a). At one end point of the continuum, a small elite group decides who will become party leader, while at the other end all members, or even all (party) voters, are allowed to make this decision. In the last few years, many parties have clearly moved in the direction of this latter point on the continuum, that is, towards more inclusive methods of leadership selection. This democratisation of leadership selection procedures varies across countries and across parties, but seems to constitute nevertheless a clear trend.

This trend is remarkable when taking into account that it involves a decision by the party elite to reduce (at least on paper) its own power. Change towards greater member involvement in leadership selection does not just happen, but is, as with any other party change, produced by a combination of exogenous factors (external stimuli that provide a reason to change) and endogenous factors (a coalition of support within the party that makes change possible or inevitable) (Harmel and Janda, 1994; Panebianco, 1988). The presence of an external stimulus does not automatically generate a change in the formal rules of a party. Critical actors within the party must be aware of these environmental stimuli, they must be supportive of the proposed change and they must be convinced that this formal change will be capable of responding to the external challenge. 
The focus in this article will be on leadership elections in which all party members have one vote ('direct member vote', 'party primaries', 'one member one vote elections', often abbreviated as 'OMOV'). Studies on the introduction of grassroots involvement in the selection of the party leader are scarce, but recently growing in number. Most studies provide anecdotal evidence about the introduction of party primaries in one particular party or country (e.g. Denham, 2009; Lisi, 2010). An exception is formed by the crosscountry analysis of William Cross and André Blais (2012) who detect decision makers and stimuli for the adoption of a direct member vote in a large number of parties in Westminster countries (the UK, Ireland, Australia, New Zealand and Canada).

The introduction of party primaries is in Cross and Blais' (2012) view a zero-sum game: more power to one (group of) party actor(s) means less power for another (group of) party actor(s). In parties operating as a 'cartel party' (Katz and Mair, 1995), party elites have become professionalised and operate often autonomously from the basis of the party in order to respond to the wishes of the electorate. Therefore, party elites only reluctantly grant more involvement to (organised) party members and only do so when they are forced to and/or when finding themselves in a weak position. In their comparative analyses of parties in Westminster political systems, Cross and Blais identify four elements that put pressure on party elites and hence create a fruitful context for introducing direct member votes: electoral defeat, being in opposition, other parties adopting direct member votes and being a new party.

Belgium does not fit in this explanatory framework, as we will demonstrate with quantitative data: the stimuli mentioned by Cross and Blais do not hold for the Belgian case. The aim of this article is to gain more insight into the reasons why Belgium differs from parties in Westminster countries in the introduction of inclusive leadership selection methods and to analyse whether the Belgian case can be a model for other countries. To that end, we complement the already existing quantitative data with the results of elite interviews.

We will now first set out the model proposed by Cross and Blais. Next, the introduction of OMOV elections in Belgian parties will be described and we will demonstrate on the basis of existing quantitative data how this introduction differs from the general pattern found in Westminster parties. Then we discuss our own empirical analysis based on elite interviews. Afterwards, we will try to formulate explanations for the differences between Westminster countries and Belgium and we will indicate why findings in Belgium can be generalised towards consensus democracies in general.

\section{Cross and Blais' Model}

It is generally assumed in the literature that party elites do not enthusiastically grant decision power to grassroots members in assigning the position of the party leader (Cross and Blais, 2012; Scarrow et al., 2001). This could be explained by the fact that modern 'electoralprofessional parties' (Panebianco, 1988) prefer to keep their hands free in order to respond quickly to voter demands. The same argument can be found in the cartel party thesis of Richard Katz and Peter Mair (1995), which states inter alia that parties become more professionalised and centralised. This implies that party members have become far less important for party elites, who are strongly focused on attracting voters by running 
professional campaigns. Party elites refrain from being bound by party members' wishes. Organised members, who are supposed to exert considerable influence, tend to be avoided in particular (Mair, 1994).

Only when they are put under pressure from the bottom up and when finding themselves in an awkward situation (electoral defeat, etc.), do party elites bow to the members' wishes and eventually introduce party primaries. Susan Scarrow et al. (2001) state that party elites prefer in such cases to hand over influence to party members, rather than to party congresses for instance in which sub-leaders and middle-level elites tend to have most influence. The general idea, following John May's (1973) law of curvilinear disparity, is that grassroots members are easier to control and take less radical positions than party activists or middle-level elites (Katz, 2001). In almost all the parties Cross and Blais investigate, power to designate the party leader has been transferred from the parliamentary party to the party membership at large. As we will see, this element is particularly relevant for the conditions in which the adoption of direct member votes takes place.

Cross and Blais (2012) identify four conditions that put pressure on party elites to broaden the leadership selectorate. A first observation by Cross and Blais is that parties are most likely to introduce party primaries when in opposition. Being in opposition causes a shift in the internal balance of power: parliamentary parties lose authority and relevance when in opposition and, consequently, their role in internal decision making is questioned and eventually reduced.

Second, new parties are more likely to adopt party primaries. Because of their newness, they still have room to experiment with internal procedures and their parliamentary parties are in general still rather small, which impedes giving them a decisive role in selecting the party leader.

Third, parties that have suffered a disappointing electoral result ${ }^{1}$ are more likely to introduce direct member votes. A bad electoral showing incites parties to revitalise themselves in order to become attractive again to voters. Electoral defeats have often been interpreted by the party elite as a request to change the internal functioning of the party. Parties have not only introduced party primaries, but they also pay lip service to such reforms and make efforts to publicise them for a wide audience (Punnett, 1992; Scarrow, 1994). Democratising leadership selection procedures is part of a broader strategic plan aimed at improving the electoral performance of a party. We should note, however, that evidence for an 'electoral dividend' following the introduction of party primaries is mixed (Scarrow, 1999).

There is yet another logic behind electoral defeat. An electoral defeat changes the internal power balance and, as a consequence, change in the leadership rules may become possible. By performing badly in the elections, the parliamentary party loses both size and authority. Consequently, it is weakened and becomes a target for party reform.

Finally, a contagion effect can be identified: if major parties have introduced party primaries, other parties of that political system tend to follow (Harmel and Janda, 1994; Scarrow et al.,2001). Parties that are operating in a competitive arena look at each other and tend to copy features of party organisation that prove to be successful. This effect fails, however, to materialise if only smaller parties adopt party primaries. It appears that party primaries constitute an element of political competition between parties.

(C) 2012 The Author. Political Studies (C) 2012 Political Studies Association POLITICAL STUDIES: 2012 
We add here a fifth condition that is not mentioned by Cross and Blais, but which comes forward in other studies, that is, membership decline (Scarrow, 1999). The aim of this introduction is making party membership more attractive. In the last few decades, an increase in mobilisation and participation has taken place outside political parties, in less conventional political outlets (Mariën et al., 2010). By copying the modus operandi of these successful alternative movements, parties believe that party membership will become attractive again. Besides attracting new members, keeping existing members on board or activating them could also be a goal.

We will now describe the situation in Belgian parties and demonstrate by using existing quantitative data that the observations for Westminster parties do not hold for Belgian parties.

\section{Party Primaries in Belgium}

The party leader is a crucial and powerful actor in Belgian politics (Fiers, 1998; Poguntke 1 and Webb, 2007) who is responsible for both the internal organisation and external activities of the party such as acting as spokesperson and appointing ministers. In general, he or she is also the electoral leader, but not the leader of the parliamentary party group, which is a separate function. Party leaders are only trumped in power by the Prime Minister and Deputy Prime Ministers (Dewachter, 2003).

If we take into account the scale of inclusiveness of the selectorate, most Belgian parties have for a long time belonged to the category using party congresses with delegates to designate their leader (see Figure 1). In practice, much power rested in the hands of the regional branches (the so-called arrondissemental ${ }^{2}$ federations) which gave instructions to their delegates to the congress. It is important to note that, unlike Westminster systems, parliamentary party groups (PPGs) have never been in charge of selecting the party leader.

All Belgian parties represented in parliament give their members nowadays a direct say in the appointment of the party leader, be it at a party conference in which all members can participate and vote or via internal elections granting each member one vote (either by postal or electronic voting, or by arranging polling booths in local party sections). The exception is the Flemish extreme right party Vlaams Belang.

Figure 1: Inclusiveness of Leadership Selection Rules
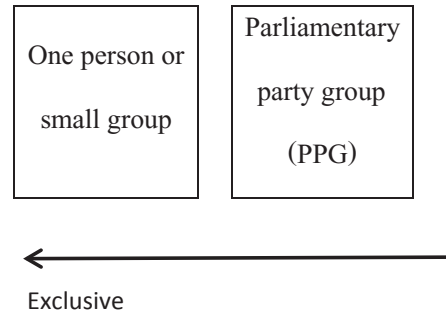
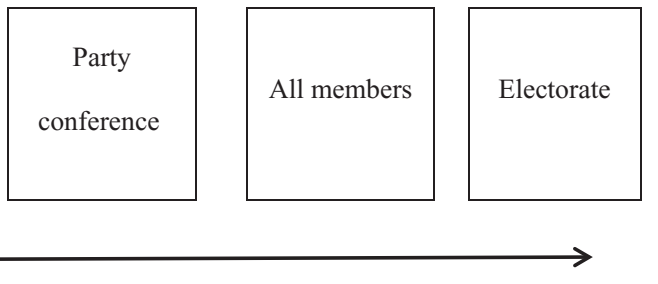

Inclusive 
Table 1: Leadership Selection Procedures in Belgium in the 1970s and Now

\begin{tabular}{llc}
\hline Party & \multicolumn{1}{c}{$1970 \mathrm{~s}$} & \multicolumn{1}{c}{$2000 \mathrm{~s}$} \\
\hline CVP/CD\&V & $\begin{array}{c}\text { Party congress with delegates voting on a list of candidates } \\
\text { nominated by the Executive National Committee }\end{array}$ & All members \\
PSC/CDH & All members & \\
SP/SP.A & Party congress with delegates: acclamation & All members \\
PS & Party congress with delegates: acclamation & All members \\
OpenVLD & Party congress with delegates & All members \\
PRL/MR & Party congress with delegates & All members \\
Groen! & Party congress with participation of all members & \\
Ecolo & Party congress with participation of all members (no party & \\
VU/N-VA & leader but a team of party secretaries) & All members \\
Vlaams Belang & Party council & Party council
\end{tabular}

Source: Author's own data.

Apart from the French-speaking Christian Democratic party PSC which has elected its party leader in 'one member, one vote' elections since the early 1970s, most reforms took place at the beginning of the 1990s. At that time, the radically transformed Flemish liberal party VLD was the first party in Flanders to introduce party primaries. Soon, most other parties followed and now almost all Belgian parties use OMOV elections. ${ }^{3}$ In comparative perspective, Belgian parties are a frontrunner in this respect.

From Table 2, it appears that, unlike for Westminster parties, no clear, straightforward pattern for the introduction of leadership elections can be distinguished. Party primaries are introduced both when parties are in opposition and in government, both after electoral setback and electoral victory, by left, right and centre parties, both when losing members and when winning members and mainly by old parties. The findings of Cross and Blais (2012) for Westminster parties do not hold for Belgian parties.

In order to gain more insight into the patterns behind the adoption of direct member votes in Belgian parties, we have complemented these quantitative data analyses with a qualitative approach using elite interviews. We conducted elite interviews with former party leaders and party secretaries from five Belgian parties ${ }^{4}$ that changed their leadership selection rules in the $1990 \mathrm{~s} .{ }^{5}$ The party secretary coordinates the internal functioning of the party. He or she is responsible for regulatory, administrative, financial and personnel elements of the party. As such, he or she is an eye-witness of the reforms but often without playing a leading role. Their testimonies are used here as a counterbalance to those of the party leaders. In the interviews, which lasted for about one hour, issues about the reasons to introduce internal elections as well as questions about internal support for this change were tackled. (For an overview of Belgian parties and details of the interviews, see Appendices 1 and 2, respectively). 


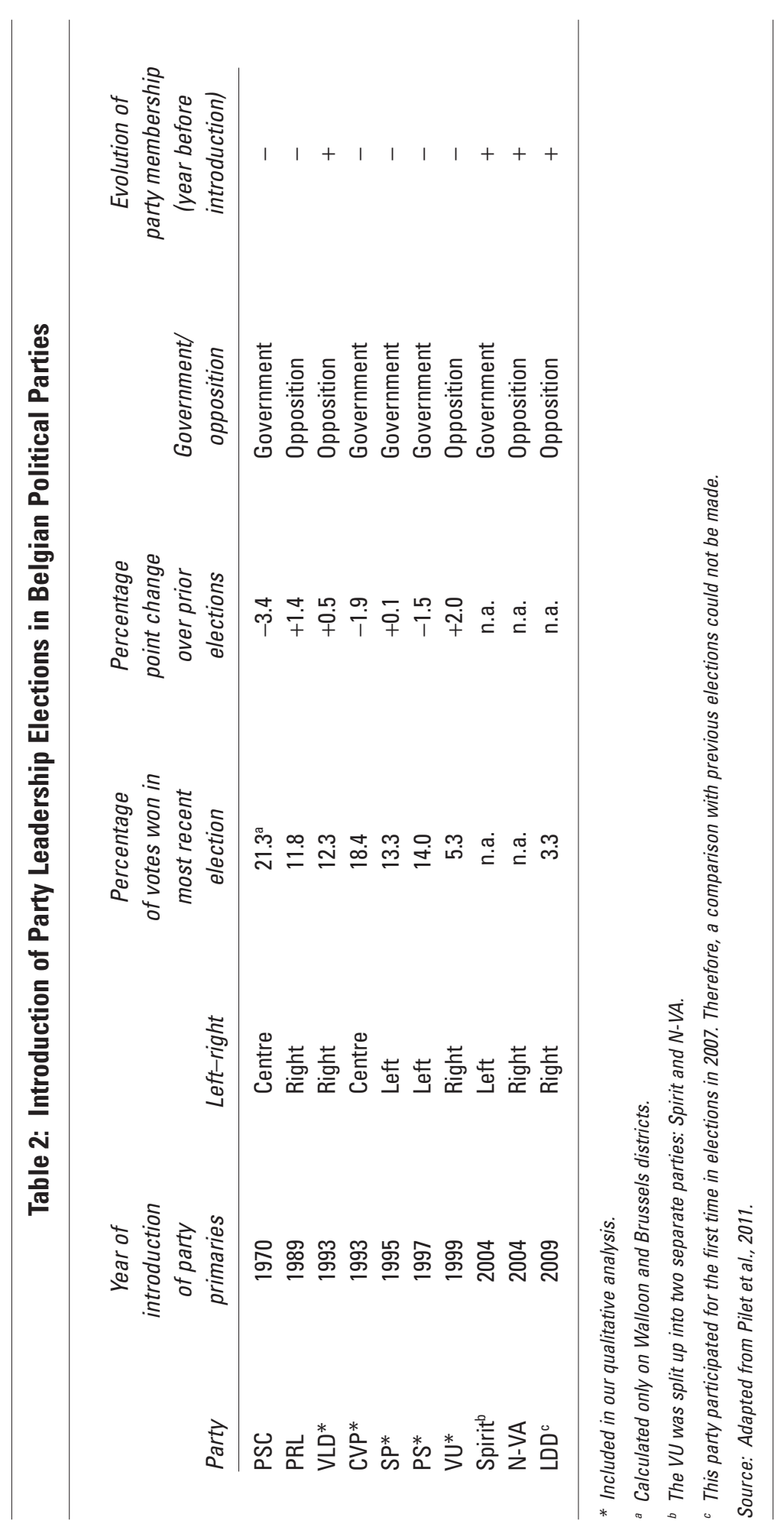

(C) 2012 The Author. Political Studies (C) 2012 Political Studies Association POLITICAL STUDIES: 2012 
In the next section, we will present the interview results, split up by the aspects identified by Harmel and Janda, that is, stimuli and decision makers.

\section{Results}

We start the analysis with a discussion of the decision makers.

\section{Decision Makers}

In all Belgian parties but one, the initiative originated from the party leader, who first tried to seek the support of the party elite (typically in the party executive) and once this support was acquired, support was sought from the grassroots and middle-level elites. Only then was the decision submitted to a party conference. The approval at party conferences was the final step in a decision-making process that started much earlier.

In the SP, the idea of a direct member vote to select the leader was talked over by the party leader with the rest of the party elite, before he defended the idea in meetings with all members which were held in every Flemish province. As a response to the scandals the PS was involved in, the party leader gathered a broad meeting including everyone who counted within the party to discuss the statutory rules. At this meeting, the principle of a direct member vote was approved and two months later an extraordinary statutory conference was held to endorse this decision. In the CVP, an unexpected replacement brought Johan Van Hecke to the position of party leader, still according to the old rules. But 'at his appointment in the party executive, he immediately launched the idea of direct elections by the members' (CVP party secretary). Party rules were quickly modified.Van Hecke himself confirms that he took the initiative, but adds that there was also a demand for reform in the party: 'The youth section of the CVP for instance had demonstrated during a party conference for a drastic reform of the party including more internal democracy'. In the VLD, party leader Guy Verhofstadt was the great champion of these reforms, which were part of the radical transformation of the party, also initiated by him.

Owing to informal contacts beforehand, proposals to adopt party primaries passed relatively easily at party conferences. There are other explanations for this smooth adoption. First of all, the proposals of the party elite were supported by other party actors too, typically the young generation. A second facilitating factor is the lack of alternatives for a party in crisis, as the PS party secretary said: 'The party was in crisis.... It was not the right moment to set up internal conflicts. It was important that the reforms passed as smoothly as possible'. A third supporting factor is the powerful position of the party leader. It is always risky for those aspiring to a political career to oppose him.

The exception to this pattern is the VU, where it was not the party leader but the party secretary who took the initiative. His main objective was bridging the gap between the grassroots and the party elite. A remarkable coalition of support has been established within the party consisting of a semi-hidden oppositional faction attempting to seize power and a party elite adopting party primaries because of the match with the party programme, without knowledge of potential internal threats. ${ }^{6}$

In Figure 2, we summarise three types of decision making. In the second model, often mentioned in the literature, party elites are forced by actors at the bottom of the party to adopt changes. The third model adopts a top-down approach. It is the party elite that 
Figure 2: Three Types of Decision-Making Processes to Adopt Direct Member Vote

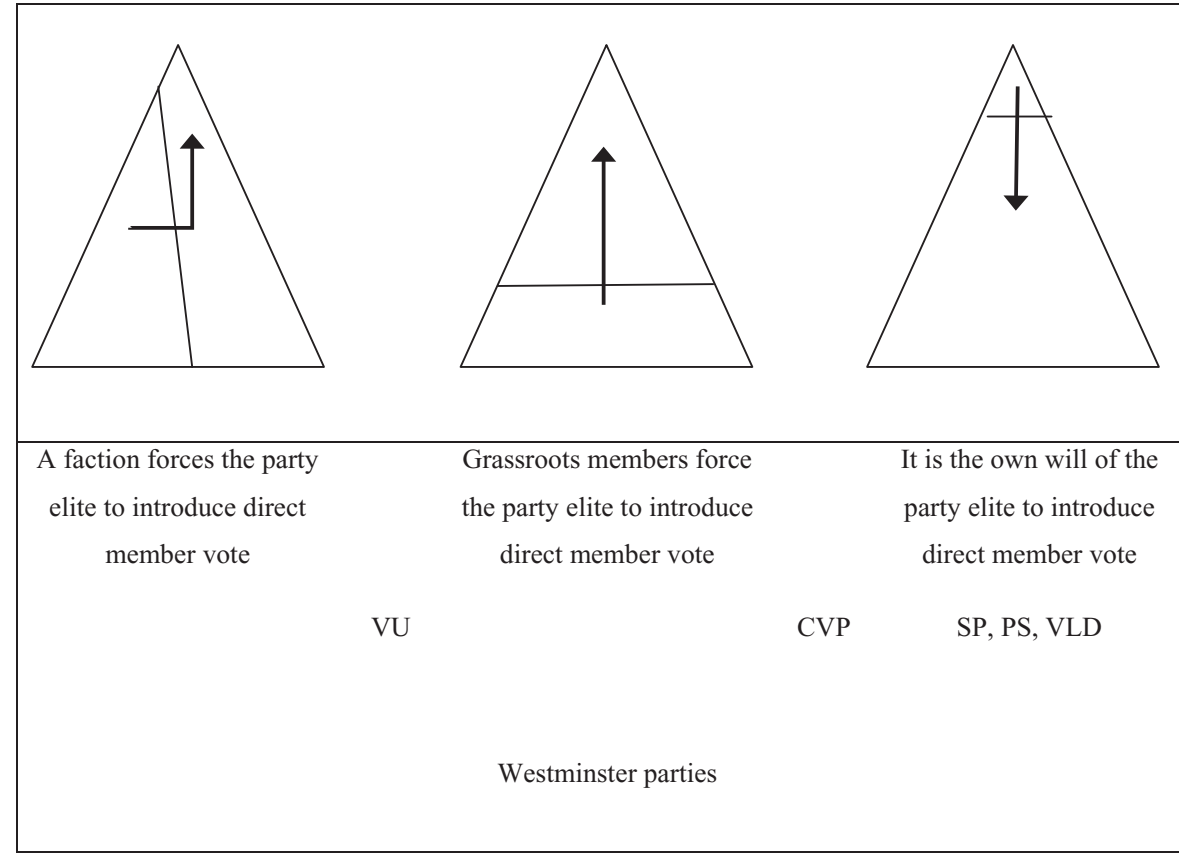

4 Source: Author's own summary; Cross and Blais, 2012.

introduces consciously and autonomously a direct member vote. Apart from these patterns, change in the party rules could also be the result of factional pressure (here the first model in the figure). Factions could simply be defined as groups within parties organised to achieve particular goals, whose members share a common identity and a common purpose (Boucek, 2009; Zariski, 1960). A direct member vote could serve the goals of a faction as it could possibly strengthen its position or even allow it to take over the party leadership (Panebianco, 1988). Therefore, party factions could be strong advocates of party primaries, putting pressure on the current party elite to introduce them. Another possible scenario is that when an oppositional faction manages to seize power in a party, it introduces these party primaries itself either because it is to its advantage or to provide a clear break with the past.

We have tried to classify the Belgian parties in Figure 2. Most of them belong to the third model: the party leadership itself takes the initiative to introduce direct member votes. The CVP is in between model 3 and model 2 since party leader Van Hecke mentioned also the pressure of young members. The Flemish nationalist VU clearly differs from the other Belgian parties, as outlined above. The adoption process could be situated between model 1 (crucial role for party factions) and model 2 (pressure from the grassroots). 
The Westminster parties studied by Cross and Blais (2012) can all be situated in the second model. Party elites only reluctantly introduce direct member votes, after increasing pressure from the grassroots.

\section{Factors Put Forward by Cross and Blais}

We will now turn our focus to factors that could stimulate the adoption of direct member votes. We will start with a discussion of the relevance for Belgian parties of the elements put forward by Cross and Blais.

A first factor is electoral defeat. As becomes clear from Table 2, unlike Westminster parties, Belgian parties introduced OMOV elections both after electoral defeat and after an electoral victory. It appears from the interviews that in the Belgian context party primaries are in general introduced when a party is in crisis, but not necessarily a crisis following an electoral defeat. Other features of a party crisis that are relevant include scandals in which the party is involved, negative press articles and bad opinion polls.

The involvement in scandals was very relevant for the two social democratic parties PS and SP. The PS party secretary testifies: 'After the Agusta and Dassault scandals ${ }^{7}$ broke out, a tornado has gone through the party, the party was completely perturbed.... I believe that these scandals have clearly put into action the plans to reform the party'. The SP party secretary adds: 'The party was completely put upside down. There were fears that, like in Italy, the social-democratic party would disappear completely.... There was a broad feeling that our party structures needed a thorough renovation then'. Reforming the party, including introducing a direct member vote, was seen as a remedy to overcome the crisis caused by scandals.

For the VU, which had just obtained an electoral victory and which had entered the regional government, one of the motives was a bad showing in the press: 'At that time, the VU suffered heavily from negative press articles ... It was my opinion that we should create something positive, with which we could go public' (VU party secretary). As for the Christian Democratic CVP, it was looking anxiously to the opinion polls before introducing OMOV elections.

This does not mean that electoral defeat does not play any role at all - it definitely does in the long run. After the 1991 elections ('Black Sunday'), ${ }^{8}$ many parties started to think about party renewal, but in some parties change only became possible much later (due to resistance from other party actors such as regional branches; see below).

In the PS, for instance, party scandals reinforced the trend towards more internal democracy and made change possible. The PS party leader said: 'After the 1991 elections with the great breakthrough of the extreme right, I would already modernise the party ... The scandals the party was involved in some years later gave me an additional reason to carry through the reforms'. They eventually adopted party primaries in 1997.

In the SP, the electoral victory at the 1995 elections functioned as an asset for the eventual introduction of more internal democracy. Plans for party renewal in the SP started in 1991 ('Black Sunday'), but strong opposition from the middle-level elites prevented party primaries to select the party leader from being adopted more quickly. The SP party secretary relates:

(C) 2012 The Author. Political Studies (C) 2012 Political Studies Association POLITICAL STUDIES: 2012 
The party leader at that time wanted to reform the party by reducing the power of the arrondissemental federations ... That was not so easy: reforming customs and traditions that have existed for several decades produced immediate reaction. He has paid cash for that. In 1993 there was a leadership election, still at the party conference with delegates of the federations. He was the only candidate, but obtained only 66 per cent of the votes. A third of the party was against him ...The federations felt that they would lose a great part of their power if further reforms would be implemented. ... This bad experience has certainly delayed the adoption of party primaries for two years or so.

It was only after an unexpected electoral victory that the new party leader found himself in such a comfortable position that he could carry through the introduction of party primaries:

It was shortly after the 1995 election campaign which was built around my person. Against all odds, we won these elections and I managed immediately to continue our participation in government. So, at that time, I could presume a great deal. Two years later, it would have been much more difficult (SP party leader).

The SP party secretary confirms this: 'He had acquired a powerful position vis-à-vis the federations. Owing to his electoral victory, he was unassailable within the party'.

In sum, a crisis in the party provides a context in which party reforms including introducing party primaries are deemed necessary and even inevitable in Belgium. A crisis is not necessarily equal to electoral defeat, however. On the contrary, an electoral victory can be a powerful instrument enabling the party elite eventually to introduce party primaries (against the resistance of middle-level elites). This contrasts with Westminster parties where parliamentary party groups are forced to hand over authority in the leadership selection process after an electoral defeat which weakens their position.

The general idea is that direct member votes contribute to an open and modern image of the party, and as such, this could lead to an increase in vote percentages. Most interviewees were convinced that introducing a direct member vote would yield them an electoral benefit. The mere organisation of party primaries is not sufficient, however. It appears to be very important to inform the electorate that you are organising them. The PS party secretary provides a case in point:

We wanted to show everyone that our party was opening up itself ... Therefore, we have prohibited proxy and postal voting and we have decided to organize polling booths in every local section.... We expected that one could see our members in the streets going to the polling booth, rendering our elections strongly visible. ... It has produced the desired effect: ... there were queues of people waiting to cast their vote. Everyone could see that social-democratic party activists could elect their leader.

Also in the CVP, party primaries were used to bring the party into the limelight:

The entire operation around Van Hecke [the new party leader] was a media operation. ... It was very important to make a good appearance in the media. Everybody knew: it is important to score, it is important to show them that we are again alive and kicking (CVP party secretary). 
Direct member votes clearly constitute an element of political marketing. Often, the aim is to generate media attention and to propagate via the media that the party has transformed itself into an open and modern party.

A second element is a contagion effect. Almost all interviewees recognise that the example of VLD, which was the first party in Flanders to introduce party primaries and which made a lot of publicity about it, has been inspiring, especially in Flanders. ${ }^{9}$ The CVP party leader admits:

The VLD was setting the political agenda with their party primaries. Then, you can do two things: either explaining why the CVP refuses to do the same, but that is difficult, very difficult, or reconciling yourself with that situation and trying to maximize the advantages of party primaries.

A third possible motivation is bending declining membership figures. Most interviewees admit that attracting new members and keeping old members on board was a goal when adopting party primaries, but only a subordinate goal. They see it as a welcome bonus, but not as the central driving force behind the introduction.

One of the reasons for this limited role is the declining importance of a large membership file. It has lost relevance due to the increase in public funding of parties and to the mediatisation of politics which allows parties to be electorally successful without having a well-developed party structure. Moreover, not all of the party elite seem to be convinced that internal elections can produce the desired effect. The CVP party secretary is one of them: 'It is always disappointing to see how few members take the effort to turn up for direct member votes ... Apparently, many members do not demand nor wish internal elections'.

In other parties, most notably in the VU and CVP, direct member votes are not so much initiated to attract new members, but to reactivate existing members: "Many people joined our party because of clientelistic reasons, to prosper their career ... It was our goal to change this and to transform the CVP into a vibrant and active party' (CVP party secretary).

\section{Two Additional Variables}

The results of our interviews confirm the quantitative observation that the factors identified by Cross and Blais do not have much predictive or explanatory power concerning the adoption of party primaries in Belgian parties. Therefore, we test two additional explanatory variables which can be derived from the cartel party thesis, that is, breaking the power of middle-level elites and the personalisation of politics.

Mair (1994), Scarrow et al. (2001) and Katz (2001) stress the fact that more formal power is granted to individual grassroots members, often at the expense of middle-level elites or party activists. In Mair's view, these ordinary members tend to be more docile and more likely to endorse candidates proposed by the party elite. We will investigate whether this feature was also a consciously considered motivation to introduce direct member votes.

From our interviews, it appears that in the SP, PS, CVP and VLD, this was one of the major motivations. The SP party leader declares: 'I admit it openly, the main goal of this introduction was breaking the power of the arrondissemental federations'. This introduction was part of a broader reform; at the same time, it was also decided to transfer the right to vote at party conferences from the regional branches (arrondissemental federations) to the 
local sections. The same is true for the PS, where it was also estimated that the arrondissemental federations had too much power.

In the CVP, the collateral social organisations that had acquired a powerful position in the party were the main target for reform:

We were a mass party, but the decision-making process in the party was dominated by the three social organizations in the party. People from the Boerenbond [farmers' organisation], NCMV [organisation of self-employed] and ACW [workers' organisation] set out the political lines in the party. They had their own troops at almost any level in the party. It was Van Hecke's aim to break through this ... by reinforcing the party leader and by giving him a mandate directly by the members (CVP party secretary).

Owing to processes of secularisation and 'de-pillarisation', social organisations could no longer provide a reservoir of guaranteed votes for a party, and consequently links became looser. On top of that, the influence of social organisations in policy making was heavily criticised by Guy Verhofstadt, leader of the major opposition party VLD. In a series of so-called 'citizen manifestos', he propagated a system of political decision making in which the power of the social organisations was reduced to the benefit of individual citizens. It was his aim to apply this new system also to his own party.

The VU is the outlier here, since in the eyes of the party leader there was absolutely no need to circumvent middle-level party elites:

Before, the party council decided on the party leader. This was a party body that was evenly composed, with presidents, secretaries and representatives of the arrondissemental levels, together about 200 people and that functioned very well. Nobody has ever formulated objections against it (VU party leader).

Broadly speaking, there were three kinds of objections against the middle-level party elites (be they arrondissemental federations or social organisations). A first complaint is that they functioned in an undemocratic way. The SP party leader explains:

In the past, a coalition formed by a handful of powerful arrondissemental federations, typically Antwerp, Ghent and Bruges, decided who would become party leader... In practice, much power rested in the hands of the president of the arrondissemental federation, who told as a feudal lord his vassals how to vote on the party conference.... This had absolutely nothing to do with democracy.

Also the PS party leader calls it an 'almost medieval system with "dukes" and "counts" '. A related point is that members of federations with a low number of members counted for almost nothing, while in a system with direct member elections, all members are equal.

A second grievance is that middle-level party elites had too much autonomy, which enabled them to block party renewal. A third problem with the influence of middle-level party elites was that they were limiting the power of the party elite, rendering the internal decision-making process more complex. The PS party leader gives a good example:

We were in government at that time, and we had to cut drastically in the budget in order to attain the Maastricht norms. That was not easy. As a party leader, I had to handle very carefully vis-à-vis the 'barons', i.e. the presidents of the federations. Every other time, it was again a bit negotiating with them. 
He estimates that this situation has changed due to the introduction of party primaries:

\begin{abstract}
Now, you still have to keep an eye on the federations, but you are no longer bound by them. The party leader now has power directly coming from the rank and file. He is no longer accountable to the federations, and can even bypass them if necessary.
\end{abstract}

The reduction of power of the federations to the advantage of the central party elite brings us to an additional motivation to adopt direct member votes, that is, strengthening the legitimacy and position of the party leader. Legitimation of the party leader by the rank and file is useful, both for internal and external reasons. Party leaders have increasingly become crucial players in the political decision-making process, especially given the process of 2 presidentialisation (Poguntke and Webb, 2007). Party leaders determine to a large extent the political line of the party and have a great impact on the electoral performance of their party. With such a large concentration of power in the hands of one person, it is estimated to be healthy to hold him or her to account via party primaries (internal reason). At the same time, a legitimised and strong party leader can take tough decisions quite autonomously, because he or she is backed by the rank and file (external reason). The CVP party leader contends that:

\begin{abstract}
A party leader assigned by a small group does not possess the same authority as a party leader supported by all members, especially when he is elected on the basis of a straightforward manifesto. After my election, I used it several times in internal discussions: 'I am only executing what was written in my manifesto, and that is what the rank and file want'.
\end{abstract}

\title{
Explanations for Differences between Westminster and Belgian Parties
}

It will be clear now that the introduction of OMOV elections in Belgian parties has passed off differently than in Westminster parties. Both the decision makers and stimuli differ. The main difference lies in the fact that Belgian party elites are themselves taking the initiative to introduce direct member votes in order to circumvent the powerful intermediate party organs (regional branches and collateral social organisations), and related to this observation, other factors (from those identified by Cross and Blais) are leading to this introduction.

Explanations for these differences can be found in a path-dependence analysis: historical and institutional facts that push the adoption process of direct member votes in a particular direction. These facts are more particularly the different position of the parliamentary party group in both political systems and the specific tradition of consociationalism in Belgium.

First, in Westminster countries, parliamentary party groups have historically played a more important role in the selection of the party leader. This can partially be explained by the fact that the party leader and the leader of the parliamentary party are two distinct positions in Belgium, while this is not so in Westminster countries. In these latter countries, when electing a party leader, the leader of the parliamentary party is also automatically chosen. In Belgium, the leader of the parliamentary party is a separate position, which is elected separately from the party leader by a different (s)electorate. References to the parliamentary party are numerous in the rationale behind the adoption of party primaries in Westminster parties: electoral defeat or being in opposition implies a weakening of the parliamentary party. In Belgium, the power to select the leader is situated elsewhere and hence a weakening of the parliamentary party does not affect the adoption process of 
Figure 3: Avoidance of Middle-Level Elites in Westminster and Belgian Parties by Introducing a Direct Member Vote, Illustrated on an Exclusive-Inclusive Continuum

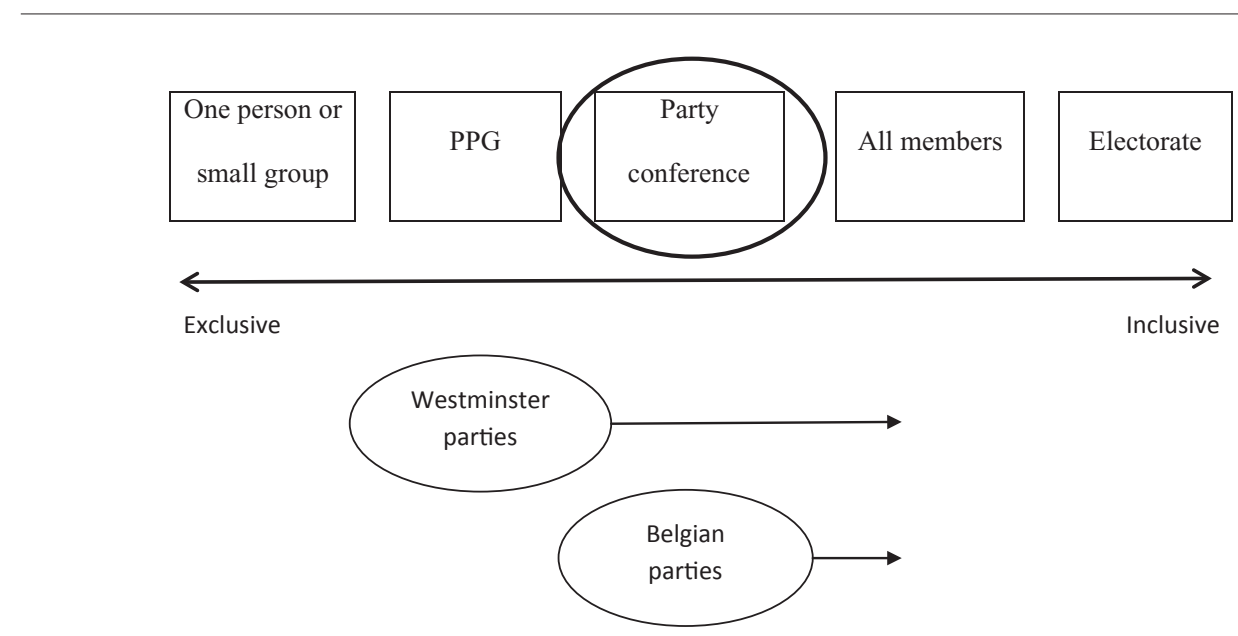

intra-party elections. Consequently, electoral defeat and being in opposition have a higher impact on the adoption process of party primaries in Westminster countries.

More broadly, who was initially in charge for selecting the party leader plays a role in determining the decision-making process. The underlying mechanism for the adoption of direct member votes is the same for both types of party, that is, avoiding too much influence for the middle-level elites (see cartel party thesis). In Belgian parties, middle-level elites (regional branches and affiliated organisations) used to exert much influence in the selection of the party leader by dominating party conferences, hence the party elite was a proponent of a reform. In Westminster parties, the parliamentary party that is a part of, or at least closely linked to, the party elite was in charge of selecting the leader. Therefore, the party elite were against a reform. If forced by circumstances, they eventually transferred power, not to the middle-level elites but directly to the individual members.

A second explanatory factor for the differences is the influence of consociationalism in Belgium. Consociationalism refers to a system of decision making in divided societies based on elite accommodation and power sharing. This tradition is, first of all, important for situating the role of intermediate levels in political parties: networks of auxiliary organisations have historically been important in Belgian parties for the incorporation of a particular subculture of people who were not politically committed..$^{10}$ But these collateral organisations also acquired considerable influence in the party, which tied the hands of the party elite. Unlike Westminster parties, party elites wanted to downplay the power of these intermediate organisations by introducing direct membership elections. Resistance by these intermediate organisations often postponed the adoption of direct member votes, rendering the link looser between electoral defeat and internal elections.

The consociational tradition is relevant for yet another reason. By introducing direct member votes, party elites linked up with the consociational tradition of symbolic mobilisation (Luther, 1999, p. 8). It was important for the bargaining position of elites in a 
consociational system to show their ability to mobilise supporters (which formed an indication of the strength of their subculture), but at the same time it was not their goal to challenge the elite's autonomy to take decisions. The introduction of OMOV fits in this tradition, as it also became apparent from the interviews that direct member votes are foremost a means to show to the outside world that the party is able to mobilise a large number of supporters.

The question now arises of whether we can deduct from the Belgian case a model valid for consensus democracies in general.

\section{Belgium as a Model for Consensus Democracies?}

Cross and Blais (2012) argue that we should analyse Westminster countries together since they share three crucial features of their political system. First, there is no discussion about identifying the party leader in any of these countries: the leader of the parliamentary party, the leader of the party organisation and the electoral leader are one and the same person. Given the fact that the leader also automatically leads the parliamentary party, these parliamentary parties historically play an important role in the selection process. Second, Westminster countries have similar political cultures and similar traditions of democratic development. These similarities include, among others, broad public support for participatory procedures, which cannot be found in less developed democracies or in consociational democracies, Cross and Blais state. A final similarity is a common structure of party authority and organisation, but this element is not further elaborated by Cross and Blais.

3 Based on Arend Lijphart's (1999) typology of Westminster and consensus democracies, we will explain that consensus democracies differ from Westminster countries in these three aspects, and that these differences matter for the adoption of intra-party primaries. First of all, strong bicameralism and federalism (typical of consensus democracies) have as an effect that there is no single parliamentary party. Either in an (almost equally powerful) second chamber and/or in a regional assembly, there is yet another parliamentary party of the same party. Since a party leader is supposed to be the leader of the party as a whole, this implies that being at the same time leader of one particular parliamentary party could cause problems of party unity. This necessitates a separation of functions, which implies that the role of the parliamentary party in selecting the party leader is more limited and consequently (as we have demonstrated above) that the process of handing over the authority to select the leader runs differently.

A second feature of consensus democracies is that in order to realise political stability, power-sharing devices and broad coalition governments are used. This implies that the distinction between government and opposition is more blurred, and also that party elites have to reach compromises. In order to do so, they must be able to take decisions quite autonomously. This supposes a passive membership, but as indicated above, also a membership that can be mobilised from time to time in order to show the party's muscle. This can be related to the argument of Cross and Blais who suppose that public support for participatory procedures will be smaller in consociational democracies. This might be true, but another element is also relevant: given the tradition of using the rank and file for elite purposes, the support for participatory procedures is likely to be higher among elites in consociational democracies. Since direct member votes fit perfectly in the tradition of 
visible but limited grassroots involvement, party elites are more likely to be enthusiastic about them than in Westminster systems.

A third characteristic of consensus democracies is the existence of a coordinated and 'corporatist' interest group system. The power of intermediate organisations is extended in the political decision-making system, but also inside parties since they are often formally linked to a particular party. Therefore, party elites have to share a part of their power with these organisations. This explains why they are often eager to introduce direct democratic procedures that circumvent these middle-level elites.

In sum, from a theoretical point of view, there are definitely elements common to consensus democracies that point to this particular path of adopting party primaries. Let us now turn to the practice.

As in Westminster countries, there are consensus democracies in which (most) parties have introduced direct member votes (the Netherlands, Portugal, etc.) and democracies in which none of the parties has done this (Austria and Sweden, for example). Whether parties in these latter countries will introduce intra-party primaries (and when) falls beyond the scope of this article. It is nevertheless striking that in these countries congress delegates are now in charge of selecting the party leader (Kenig, 2009b) and not the parliamentary party as in Westminster countries. This confirms the expectation that handing over authority to select the party leader originates from a different position in consensus democracies.

Another more important question is whether parties that have adopted direct member votes have followed the 'Belgian path', that is, party elites taking the initiative to overcome the power of middle-level elites. At this moment, however, we lack empirical in-depth evidence about these adoption processes. There are, however, some indications based on cursory analyses that confirm the 'Belgian path'. In the Netherlands, the link between electoral defeat and the adoption of party primaries is loose: often several years after losing elections, party primaries are eventually introduced (Voerman, 2005). Another element confirming the 'Belgian path' refers to the resistance of regional party sections (called 'party barons') in the liberal partyVVD against the party elite's plans to introduce a direct member vote. And in Portuguese parties, party primaries are primarily used to defeat the internal opposition and to enhance the legitimisation of the party leader (Lisi, 2010). It is also striking that the socialist party in Portugal introduced OMOV elections after electoral success and while leading a successful government.

This anecdotal evidence seems to confirm our thesis. However, more in-depth analyses are needed in order to prove that the process outlined above applies to all consensus democracies.

\section{Discussion and Conclusion}

Political parties in modern democracies are adopting more inclusive procedures to select their party leader. More particularly, grassroots members are increasingly involved in this process, most notably by having a direct vote in leadership elections.

This change could be explained by a combination of exogenous (motives) and endogenous factors (internal coalitions of support). According to the cartel party thesis, party elites tend to be very powerful and want to keep their hands free to respond to voter demands. 
Cross and Blais (2012) contend, therefore, that Westminster party elites only reluctantly transfer more power from the parliamentary party group to party members. The party elites only do so when they are forced to and/or when finding themselves in a weak position: after an electoral defeat, when in opposition, when other parties are adopting direct member votes or when the party is new.

The situation in Belgium is different, as we have demonstrated in this article.

In all Belgian parties but one, the current party elite was very keen on introducing party primaries and itself took the initiative to carry them through. The mechanism at work, however, is the same as in Westminster parties, but the starting position differs, which renders the decision-making process completely different. In both Belgian and Westminster parties, party elites try to avoid too much power for the middle-level elites (party congresses, regional branches, collateral social organisations). In Westminster parties, the parliamentary party was initially in charge of selecting the party leader. Taking away power from the parliamentary party involves weakening the party elite and possibly strengthening middle-level elites. Consequently, party elites are reluctant to introduce party primaries. In Belgian parties, on the contrary, party congresses using a system of delegates, which empowers organised middle-level elites, were in charge to designate the leader. Introducing direct member votes means taking away power from the middle-level elites, which is applauded by the party elite.

Consequently, the motives for introducing a direct member vote are different. Whereas in Westminster countries electoral defeat implies a weakening of the parliamentary party, which gives proponents of reform an argument to take away (some of) its power, this is not the case in Belgium. On the contrary, a good electoral result could empower the party leader in order eventually to overcome the resistance of middle-level elites. Westminster parties and Belgian parties share the fact that electoral defeat could induce parties to consider reforming the party, but whereas in Westminster parties the weakening of parliamentary parties supports these tendencies, in Belgian parties a strengthening of the party elite following an electoral victory at the next elections is helpful, and sometimes even necessary, to overcome the resistance of middle-level elites. Moreover, it seems better to use party crisis as context rather than electoral defeat which is more limited, since bad opinion polls, involvement in party scandals and negative press articles could have the same effect.

The decline in membership figures is also often cited as one of the major driving forces behind the introduction of internal elections (Scarrow, 1999). From our interviews, it appears, however, that this is at most a subordinate goal because party elites estimate, for various reasons, that voters are far more important than party members.

We have indicated in this article that other patterns (than those sketched in the literature up to now) of adopting party primaries occur and we have tried to sketch these patterns in detail based on the Belgian situation. We have also argued that there are theoretical reasons to expect that the pattern found in Belgium will occur in other consensus democracies. Consensus democracies share three crucial characteristics of their political system which have an impact on the adoption process of party primaries. Further in-depth studies in these countries should verify whether empirical evidence confirms these theoretical expectations.

(C) 2012 The Author: Political Studies (C) 2012 Political Studies Association POLITICAL STUDIES: 2012 


\title{
Appendix 1: List of Belgian Political Parties
}

CD\&V (previously CVP): Flemish Christian democrats

$\mathrm{CDH}$ (previously PSC): French-speaking Christian democrats

SP.A (previously SP): Flemish social democrats

PS: French-speaking social democrats

VLD (previously PVV): Flemish liberals

MR (previously PRL): French-speaking liberals

Groen! (previously Agalev): Flemish greens

Ecolo: French-speaking greens

LDD (founded in 2006): populist Flemish liberals

VU (split up in 2001): Flemish regionalist party

N-VA (former members of VU): Flemish regionalist party

Spirt (later SLP, former members of VU): Flemish regionalist party with a social-liberal profile, now disappeared

Vlaams Belang (previously Vlaams Blok): Flemish extreme right party

FN: French-speaking extreme right party

\section{Appendix 2: List of Interviews}

\begin{tabular}{llllll} 
Party & Year & \multicolumn{1}{c}{ Name } & Function in year X & \multicolumn{1}{c}{ Date } & \multicolumn{1}{c}{ Location } \\
\hline VLD & 1993 & Clair Ysebaert & Party secretary & 31 January 2011 & Brussels \\
CVP & 1993 & Johan Van Hecke & Party leader & 16 March 2011 & By telephone \\
CVP & 1993 & Luc Willems & Party secretary & 11 February 2011 & Brussels \\
SP & 1995 & Louis Tobback & Party leader & 8 February 2011 & Leuven \\
SP & 1995 & Linda Blomme & Party secretary & 10 February 2011 & Antwerp \\
PS & 1997 & Philippe Busquin & Party leader & 15 February 2011 & Seneffe \\
PS & 1997 & Jean-Pol Baras & Party secretary & 1 February 2011 & Brussels \\
VU & 1999 & Patrik Vankrunkelsven & Party leader & 18 January 2011 & Laakdal \\
VU & 1999 & Laurens Appeltans & Party secretary & 14 January 2011 & Leuven \\
VU & 1999 & Eric Defoort & Deputy party leader & 9 March 2011 & Ghent
\end{tabular}

(Accepted: 18 April 2012)

\begin{abstract}
About the Author
Bram Wauters is Assistant Professor at the Faculty of Public and Business Administration of the University College Ghent and Guest Professor at the Faculty of Political and Social Sciences of Ghent University. His research interests include political representation, electoral systems and political parties. He has recently published on these topics in journals such as Party Politics, Journal of Ethnic \& Migration Studies, West European Politics, Journal of Legislative Studies, Local Government Studies and Representation. He is also (co-)author of book chapters in volumes on party leadership selection across Europe and on parliamentary representation in the twenty-first century. Bram Wauters, Department of Business Administration and Public Management, University College Ghent, Henleykaai 84 (building G), 9000 Ghent, Belgium; email: bram.wauters@hogent.be
\end{abstract}




\section{Notes}

An earlier version of this article was presented at the ECPR Joint Sessions of Workshops in St Gallen in workshop 7, 'The Selection of Party Leaders: Origins, Methods and Consequences'. I would like to thank participants for their valuable comments. I am also grateful to the former party leaders and party secretaries who were ready to devote some of their time to my interviews and to speak openly about the introduction of leadership primaries in their party.

1 It should be noted that an electoral defeat is subject to interpretation: expectations also play a role in determining whether elections are lost or not. If the score of a party is lower than in previous elections but higher than expected, it is not necessarily interpreted as a defeat.

2 Formerly, electoral districts coincided with 'arrondissements', administrative entities that typically grouped several local municipalities together. Parties were organised accordingly in powerful regional branches (arrondissemental federations). In 2003 the electoral districts for the House of Representatives were enlarged to the level of the provinces, typically grouping together a handful of arrondissements. Most party structures were soon adapted accordingly.

3 Non-members are not granted the right to vote. The Flemish liberal democratic party VLD experimented in its early years with a system of registered voters, but this was quickly abolished.

4 Ideally, we should have interviewed also people belonging to the middle-level elites, such as leaders of regional branches (arrondissemental federations) or chairs of party conferences. Since it appeared to be very difficult to identify these people (taking into account that the introduction of leadership elections happened fifteen or twenty years ago) and to find their contact details, we refrained from interviewing these people.

5 Parties that adopted leadership elections earlier were difficult to study because of practical reasons. From the PRL for instance, the party secretary and both co-leaders of that time have already died. Parties that adopted them later were less relevant since they all were successors or spin-offs of existing parties that already used leadership elections.

6 At that time, the party was split into two factions (Wauters, 2005), which were both surprised by the proposal of the party secretary, but supported it albeit for different reasons. The incumbent party elite were in favour because of the general democratic principles that matched with the party programme and because of the potential positive media exposure. The oppositional faction, which had developed some sort of organisation without the party elite's knowledge, was a proponent because these elections could reveal the divergence between members' views and the party elite.

7 Party finance scandal, which broke out in the course of the 1990s and which shocked Belgian society. Both French-speaking and Flemish social democratic ministers had received bribe money for the approval of contracts between the Belgian government and the business companies Agusta and Dassault.

8 The 1991 elections featured the first great breakthrough of the extreme right party Vlaams Blok, which increased its number of seats from two to twelve. All established parties lost several seats. The results of these elections came as a shock for many politicians and observers, and the day was quickly labelled 'Black Sunday'.

9 Belgium is a federal country composed of three regions and three communities. In fact, there are two party systems: a Flemish one and a French-speaking one, which operate quite autonomously from each other. Except for the bilingual electoral district Brussels-Halle-Vilvoorde, parties from different party systems do not enter into competition with each other. Therefore, when a Flemish party adopts leadership elections, the contagion effect is expected to materialise in Flanders, and not so much in the French-speaking part of Belgium.

10 It is perhaps no coincidence that the VU, the only party diverging from the Belgian pattern, did not have a well-developed 'pillar' of related organisations.

\section{References}

Boucek, F. (2009) 'Rethinking Factionalism:Typologies, Intra-party Dynamics and Three Faces of Factionalism', Party Politics, 15 (4), 455-85.

Cross, W. and Blais, A. (2012) 'Who Selects the Party Leader?', Party Politics, 18 (2), 127-50.

Denham, A. (2009) 'From Grey Suits to Grass Roots: Choosing Conservative Leaders', British Politics, 4 (2), 217-35.

Dewachter, W. (2003) Van Oppositie Tot Elite: Over Macht, Visie En Leiding. Leuven: Acco.

Fiers, S. (1998) Partijvoorzitters in Belgie of 'Le Parti, C'est Moi'? Leuven: Acco.

Harmel, R. and Janda, K. (1994) 'An Integrated Change', Journal of Theoretical Politics, 6 (3), 259-87.

Katz, R. (2001) 'The Problem of Candidate Selection and Models of Party Democracy', Party Politics, 7 (3), 277-96.

Katz, R. and Mair, P. (1995) 'Changing Models of Party Organization and Party Democracy: The Emergence of the Cartel Party', Party Politics, 1 (1), 5-28.

Kenig, O. (2009a) 'Classifying Party Leaders' Selection Methods in Parliamentary Democracies', Journal of Elections, Public Opinion and Parties, 19 (4), 433-47.

Kenig, O. (2009b) 'The Democratization of Party Leaders' Selection Methods: Canada in Comparative Perspective'. Paper presented at Canadian Political Science Association Annual Conference, 27-29 May, University of Carleton, Ottawa.

LeDuc, L. (2001) 'Democratizing Party Leadership Selection', Party Politics, 7 (3), 323-41.

Lisi, M. (2010) 'The Democratization of Party Leadership Selection:The Portuguese Experience', Portuguese Journal of Social Science, 9 (2), 127-49.

Luther, K. R. (1999) 'A Framework for the Comparative Analysis of Political Parties and Party Systems in Consociational Democracy', in K. R. Luther and K. Deschouwer (eds), Party Elites in Divided Societies: Political Parties in Consociational Democracy. London: Routledge, pp. 3-19.

Mair, P. (1994) 'Party Organization: From Civil Society to the State', in R. Katz and P. Mair (eds), How Parties Organize: Change and Adaptation in Party Organizations in Western Democracies. London: Sage, pp. 1-22. 
Mariën, S., Hooghe, M. and Quintelier, E. (2010) 'Inequalities in Non-institutionalised Forms of Political Participation: A Multi-level Analysis of 25 Countries', Political Studies, 58 (1), 187-213.

May, J. D. (1973) 'Opinion Structure of Political Parties: The Special Law of Curvilinear Disparity', Political Studies, 21 (2), $135-51$.

Panebianco, A. (1988) Political Parties: Organization and Power. Oxford: Oxford University Press.

Pilet, J.-B., Cross, W. and Blais, A. (2011) 'Does Consociationalism Matter? Leadership Selection in Belgium in Comparative Perspective'. Paper presented at the ECPR Joint Sessions, St Gallen, 12-17 April.

Poguntke, T. and Webb, P. (eds) (2007) The Presidentialization of Politics: A Comparative Study of Modern Democracies. Oxford: Oxford University Press.

Punnett, R. M. (1992) Selecting the Party Leader: Britain in Comparative Perspective. New York: Harvester Wheatsheaf.

Scarrow, S. (1994) 'The 'Paradox of Enrollment': Assessing the Costs and Benefits of Party Memberships', European Journal of Political Research, 25 (1), 41-60.

Scarrow, S. (1999) 'Parties and the Expansion of Direct Democracy: Who Benefits?', Party Politics, 5 (3), $341-62$.

Scarrow, S., Webb, P. and Farrell, D. (2001) 'From Social Integration to Electoral Contestation: The Changing Distribution of Power within Political Parties', in R. J. Dalton and M. Wattenberg (eds), Parties without Partisans: Political Change in Advanced Industrial Democracies. Oxford: Oxford University Press, pp. 129-51.

Voerman, G. (2005) 'Plebiscitaire partijen? Over de vernieuwing van de Nederlandse partijorganisaties', in G. Voerman (ed.), Jaarboek DNPP 2004. Groningen: DNPP, pp. 217-44.

Wauters, B. (2005) 'Divisions within an Ethno-regional Party:The Volksunie in Belgium', Regional and Federal Studies, 15 (3), 329-52.

Wauters, B. (2010) 'Explaining Participation in Intra-party Elections: Evidence from Belgian Political Parties', Party Politics, 16 (2), 237-59.

Zariski, R. (1960) 'Party Factions and Comparative Politics: Some Preliminary Observations', Midwest Journal of Political Science, 4 (1), 27-51. 


\section{AUTHOR QUERY FORM}

Dear Author,

During the preparation of your manuscript for publication, the questions listed below have arisen. Please attend to these matters and return this form with your proof.

Many thanks for your assistance.

\begin{tabular}{|l|l|l|}
\hline $\begin{array}{l}\text { Query } \\
\text { References }\end{array}$ & Query & Remarks \\
\hline 1 & $\begin{array}{l}\text { AUTHOR: Poguntke and Webb, 2005 has been changed } \\
\text { to Poguntke and Webb, 2007 so that this citation matches } \\
\text { the Reference List. Please confirm that this is correct. }\end{array}$ & \\
\hline 2 & $\begin{array}{l}\text { AUTHOR: Poguntke and Webb, 2005 has been changed } \\
\text { to Poguntke and Webb, 2007 so that this citation matches } \\
\text { the Reference List. Please confirm that this is correct. }\end{array}$ & \\
\hline 3 & $\begin{array}{l}\text { AUTHOR: Lijphart (1999) has not been included in the } \\
\text { Reference List, please supply full publication details. }\end{array}$ & \\
\hline 4 & $\begin{array}{l}\text { AUTHOR: Cross \& Blais (2011) has been changed to } \\
\text { Cross \& Blais (2012) so that this citation matches the } \\
\text { Reference List. Please confirm that this is correct. }\end{array}$ & \\
\hline 5 & $\begin{array}{l}\text { AUTHOR: Figure } 3 \text { has not been mentioned in the text. } \\
\text { Please cite the figure in the relevant place in the text. }\end{array}$ & \\
\hline 6 & $\begin{array}{l}\text { AUTHOR: Table 1 has not been mentioned in the text. } \\
\text { Please cite the table in the relevant place in the text. }\end{array}$ & \\
\hline
\end{tabular}


Required software to e-Annotate PDFs: Adobe Acrobat Professional or Adobe Reader (version 8.0 or above). (Note that this document uses screenshots from Adobe Reader $\mathrm{X}$ )

The latest version of Acrobat Reader can be downloaded for free at: http://get.adobe.com/reader/

Once you have Acrobat Reader open on your computer, click on the Comment tab at the right of the toolbar:

닙

This will open up a panel down the right side of the document. The majority of tools you will use for annotating your proof will be in the Annotations section, pictured opposite. We've picked out some of these tools below:

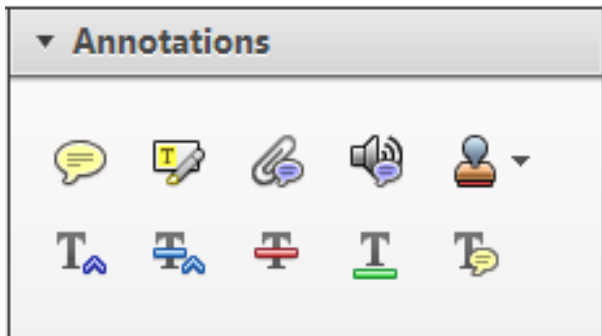

1. Replace (Ins) Tool - for replacing text.

Strikes a line through text and opens up a text box where replacement text can be entered.

\section{How to use it}

- Highlight a word or sentence.

- Click on the Replace (Ins) icon in the Annotations section.

- Type the replacement text into the blue box that appears.

Idard tramework for the analysis of $\mathrm{m}$ icy-Nevertheless, it also led to exog،

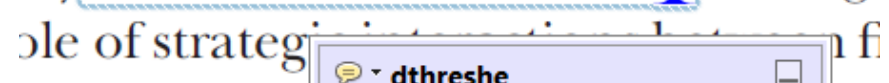
aber of comp 08/06/2011 15:58:17

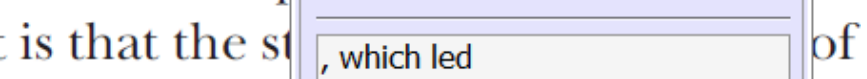
nain compo: be level, are exc nc

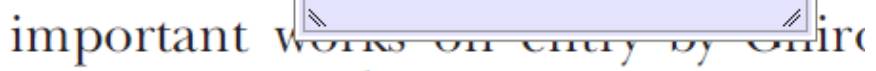
M heneferth) ${ }^{1}$ we anen the 'hlark $\mathrm{h}$

3. Add note to text Tool - for highlighting a section to be changed to bold or italic.

T Highlights text in yellow and opens up a text box where comments can be entered.

\section{How to use it}

- Highlight the relevant section of text.

- Click on the Add note to text icon in the Annotations section.

- Type instruction on what should be changed regarding the text into the yellow box that annears.

namic responses of mark ups ent with the VAR evidence

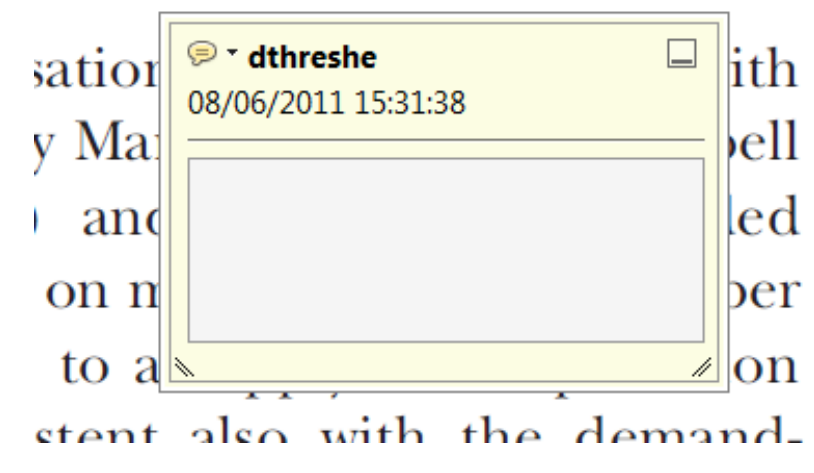

2. Strikethrough (Del) Tool - for deleting text.

Thikes a red line through text that is to be deleted.

\section{How to use it}

- Highlight a word or sentence.

- Click on the Strikethrough (Del) icon in the Annotations section.

there is no room tor extra prohts al c ups are zero and the number of ret) values are not determined by Blanchard and Kiyotaki (1987), rfect competition in general equilil ts of aggregate demand and supply lassical framework assuming monol eon an evorenois number of firms

\section{Add sticky note Tool - for making notes at} specific points in the text.

Marks a point in the proof where a comment needs to be highlighted.

\section{How to use it}

- Click on the Add sticky note icon in the Annotations section.

- Click at the point in the proof where the comment should be inserted.

- Type the comment into the yellow box that appears.

lallu allu suppiy silucks. hivst vi

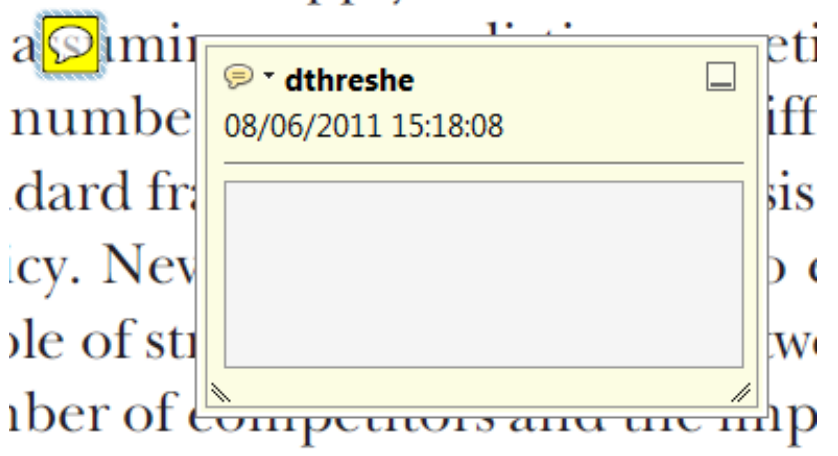

is that the structure of the secto 
5. Attach File Tool - for inserting large amounts of text or replacement figures.

Inserts an icon linking to the attached file in the appropriate pace in the text.

How to use it

- Click on the Attach File icon in the Annotations section.

- Click on the proof to where you'd like the attached file to be linked.

- Select the file to be attached from your computer or network.

- Select the colour and type of icon that will appear in the proof. Click OK.

E N D

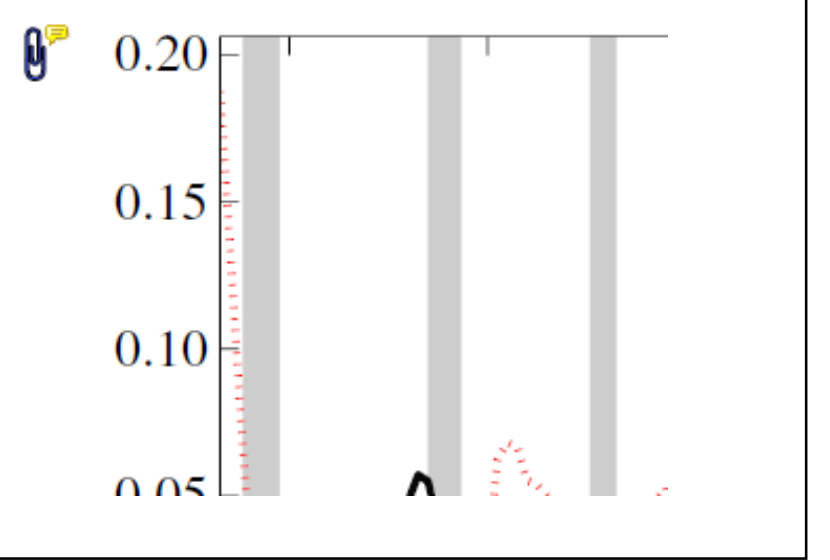

6. Add stamp Tool - for approving a proof if no corrections are required.

- Inserts a selected stamp onto an appropriate place in the proof

\section{How to use it}

- $\quad$ Click on the Add stamp icon in the Annotations section.

- $\quad$ Select the stamp you want to use. (The Approved stamp is usually available directly in the menu that appears).

- Click on the proof where you'd like the stamp to appear. (Where a proof is to be approved as it is, this would normally be on the first page).

of the Dusiness cycie, starting with the on perfect competition, constant ret

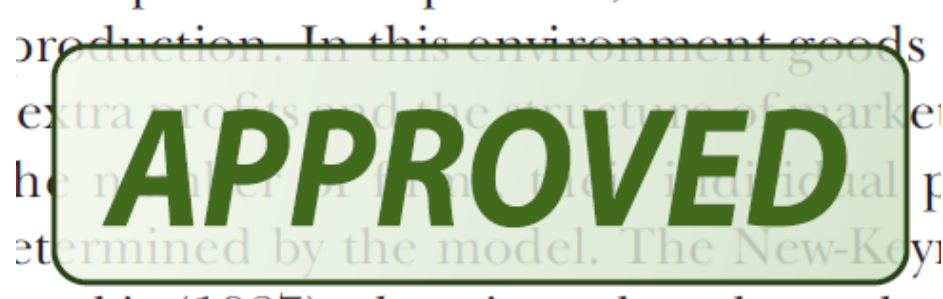

otaki (1987), has introduced produc general equilibrium models with nomin
- Drawing Markups

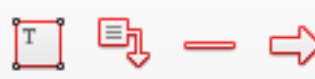

$0 \square \sqrt{6} D$

\section{How to use it}

- Click on one of the shapes in the Drawing Markups section.

- Click on the proof at the relevant point and draw the selected shape with the cursor.

- To add a comment to the drawn shape, move the cursor over the shape until an arrowhead appears.

- Double click on the shape and type any text in the red box that appears.
7. Drawing Markups Tools - for drawing shapes, lines and freeform annotations on proofs and commenting on these marks.

Allows shapes, lines and freeform annotations to be drawn on proofs and for comment to be made on these marks.

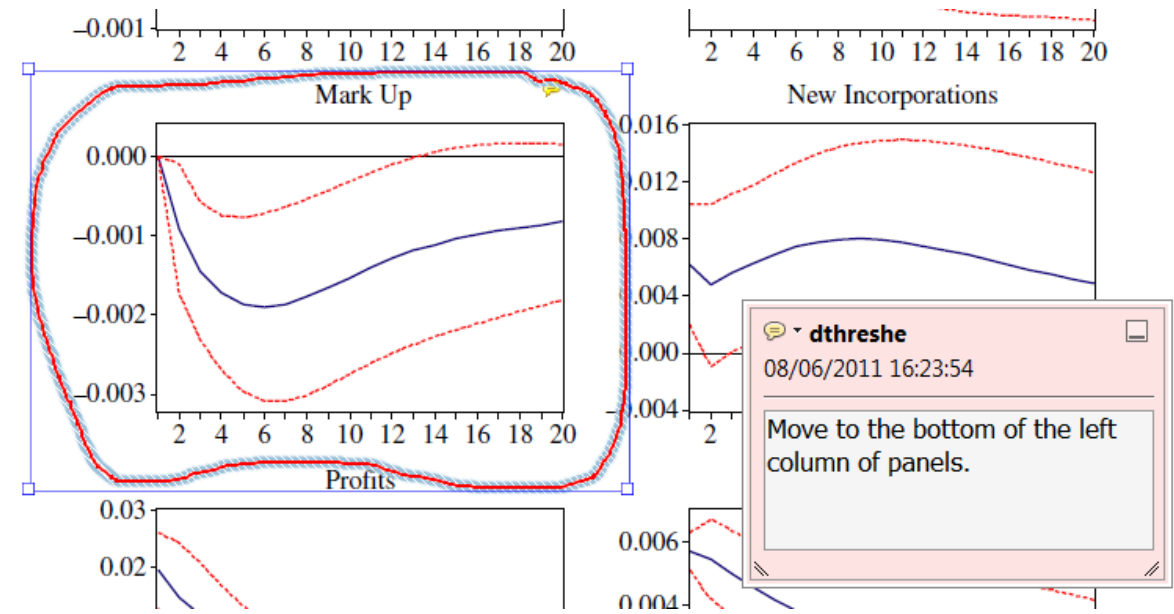

For further information on how to annotate proofs, click on the Help menu to reveal a list of further options:

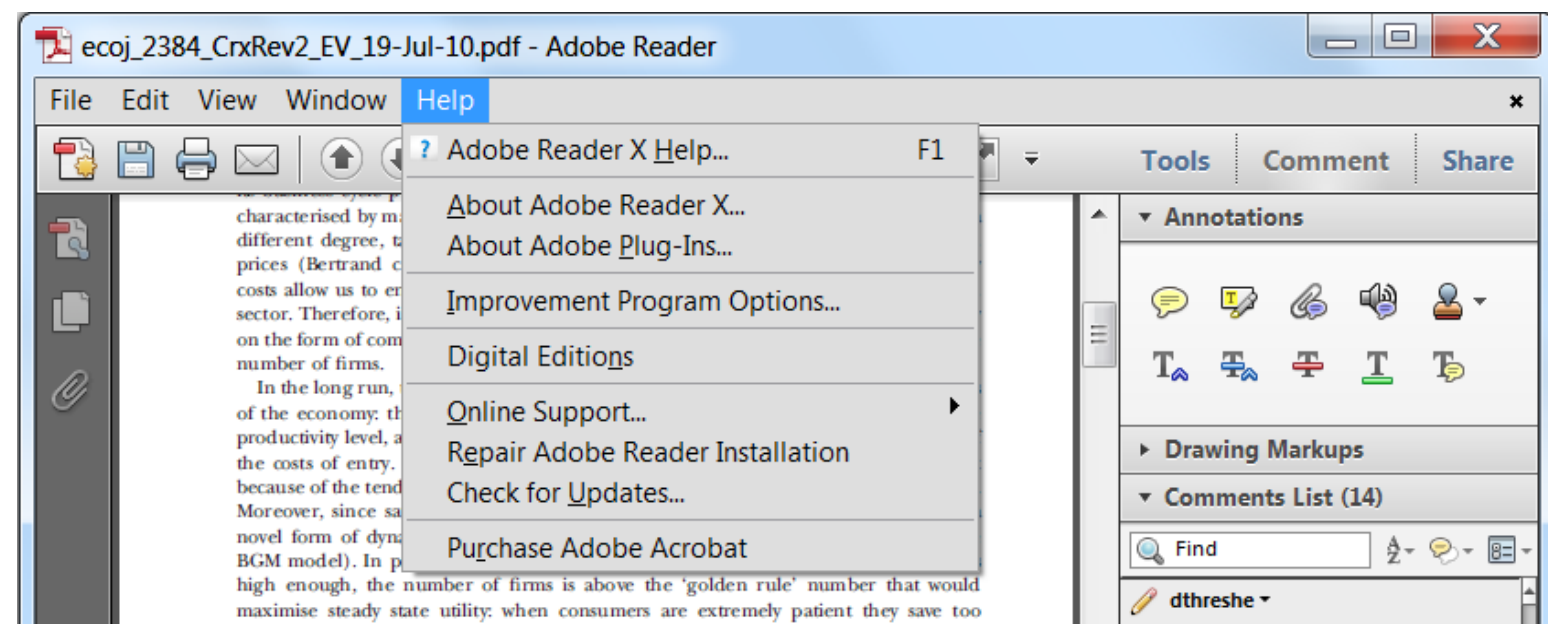

